Article

\title{
Substituent Effects in the Crystal Packing of Derivatives of $4^{\prime}$-Phenyl-2, $2^{\prime}: 6^{\prime}, 2^{\prime \prime}$-Terpyridine
}

\author{
Y. Maximilian Klein $\mathbb{D}$, Alessandro Prescimone $\mathbb{D}$, Mariia Karpacheva, Edwin C. Constable $\mathbb{D}$ \\ and Catherine E. Housecroft *(D)
}

Department of Chemistry, University Basel, BPR 1096, Mattenstrasse 24a, CH-4058 Basel, Switzerland; maximilian.klein@psi.ch (Y.M.K.); alessandro.prescimone@unibas.ch (A.P.);

mariia.karpacheva@unibas.ch (M.K.); edwin.constable@unibas.ch (E.C.C.)

* Correspondence: catherine.housecroft@unibas.ch; Tel.: +41-61-207-1008

Received: 4 February 2019; Accepted: 17 February 2019; Published: 20 February 2019

check for updates

Abstract: We report the preparation of a series of new $4^{\prime}$-substituted $2,2^{\prime}: 6^{\prime}, 2^{\prime \prime}$-terpyridines: $4^{\prime}$-(3,5-dimethylphenyl)-2,2': $6^{\prime}, 2^{\prime \prime}$-terpyridine (2), $4^{\prime}$-(3-fluoro-5-methylphenyl)-2,2': $6^{\prime}, 2^{\prime \prime}$-terpyridine (3), $4^{\prime}$-(3,5-difluorophenyl)-2, $2^{\prime}: 6^{\prime}, 2^{\prime \prime}$-terpyridine (4), and $4^{\prime}$-(3,5- bis(trifluoromethyl)phenyl)$2,2^{\prime}: 6^{\prime}, 2^{\prime \prime}$-terpyridine (5). The compounds have been characterized by mass spectrometry, solid-state IR spectroscopy and solution NMR and absorption spectroscopies. The single-crystal X-ray diffraction structures of 3, 5 and $\mathbf{6} \cdot \mathrm{EtOH}\left(\mathbf{6}=4^{\prime}\right.$-(3,5-bis(tert-butyl)phenyl)-2, $2^{\prime}: 6^{\prime}, 2^{\prime \prime}$-terpyridine) have been elucidated. The molecular structures of the compounds are unexceptional. Since 3 and 5 crystallize without lattice solvent, we are able to understand the influence of introducing substituents in the $4^{\prime}$-phenyl ring and compare the packing in the structures with that of the previously reported $4^{\prime}$-phenyl-2,2':6 $2^{\prime} 2^{\prime \prime}$-terpyridine (1). On going from 1 to 3 , face-to-face $\pi$-stacking of pairs of 3-fluoro-5-methylphenyl rings contributes to a change in packing from a herringbone assembly in 1 with no ring $\pi$-stacking to a layer-like packing. The latter arises through a combination of $\pi$-stacking of aromatic rings and $\mathrm{N} \ldots \mathrm{H}-\mathrm{C}$ hydrogen bonding. On going from 3 to $5, \mathrm{~N} \ldots \mathrm{H}-\mathrm{C}$ and $\mathrm{F}$... H-C hydrogen-bonding is dominant, supplemented by $\pi$-stacking interactions between pairs of pyridine rings. A comparison of the packing of molecules of 6 with that in 1,3 and 5 is difficult because of the incorporation of solvent in $\mathbf{6} \cdot \mathrm{EtOH}$.

Keywords: $2,2^{\prime}: 6^{\prime}, 2^{\prime \prime}$-terpyridine; crystal structure; crystal packing; trifluoromethyl; fluoro; tert-butyl

\section{Introduction}

The relevance of energetically small intermolecular interactions in determining the arrangement of molecules and molecular ions in crystal lattices is well documented [1,2]. In particular, the role of hydrogen-bonding in crystal packing has been widely investigated, and specific attention has been paid to the varying types of hydrogen bonds, ranging from the strongest interaction in $\left[\mathrm{HF}_{2}\right]^{-}[3]$ to non-classical (weak) hydrogen bonds $[2,4,5]$. One of the weakest hydrogen bonds is the $\mathrm{CH} \ldots \pi$ contact [2], but despite its weakness, it plays a substantial role in crystal packing [6,7]. Although the interpretation of crystal packing in terms of donor ... acceptor interactions is commonly discussed in the literature, the combination of electron donors (e.g., N, O, F, $\pi$-systems) and acceptors (e.g., $\mathrm{O}-\mathrm{H}$, $\mathrm{N}-\mathrm{H}, \mathrm{C}-\mathrm{H}$ units) within a molecule does not necessarily result in a predetermined organization of molecules in the solid state. Statistical analysis of structures in the Cambridge Structural Database demonstrates that many more $\mathrm{H}$... acceptor interactions, especially weak $\mathrm{C}-\mathrm{H}$... X contacts occur in crystals than would be expected, based on a model of random contacts [8]. However, Lo Presti has pointed out that, from a crystal-engineering point of view, weak $\mathrm{C}-\mathrm{H} \ldots \mathrm{X}$ interactions, on their own, are unlikely to be a significant thermodynamic driving force toward a specific crystal form $[9,10]$. 
This is likely to be the underlying reason for the difficulty in controlling the crystallization output in a purely chemical perspective. This leads to a general problem of predicting the outcome of assemblies in crystalline materials, and crystal structure prediction is now a mature, but complex, field (see for example, References [11-15]).

Over the last four decades, we have been particularly interested in the use of terpyridine ligands, principally $2,2^{\prime}: 6^{\prime}, 2^{\prime \prime}$-terpyridine (tpy) and its derivatives $[16,17]$ and $3,2^{\prime}: 6^{\prime}, 3^{\prime \prime}$ - and $4,2^{\prime}: 6^{\prime}, 4^{\prime \prime}$-terpyridines $[18,19]$. Crystal packing in tpys and tpy-containing metal coordination compounds is frequently dictated by face-to-face $(\pi \ldots \pi)$ and edge-to-face interactions $(\mathrm{CH} \ldots$ $\pi$ ) between aromatic rings. The recognition of face-to-face $\pi$-stacking between arene rings as a charge transfer interaction [20] was a significant development in our understanding of crystal-packing effects. Janiak's seminal review of $\pi$-stacking between aromatic nitrogen-containing ligands [21] greatly influenced descriptions of packing interactions in systems involving 2,2'-bipyridine (bpy) and tpy domains. McMurtrie and Dance were influential in recognizing the way in which $\left\{\mathrm{M}(\mathrm{tpy})_{2}\right\}$ units embrace one another and defined a number of motifs that are characteristic of embraces between pairs of $4^{\prime}$-Phtpy units ( $4^{\prime}$-Phtpy $=4^{\prime}$-phenyl-2,2': $6^{\prime}, 2^{\prime \prime}$-terpyridine) in metal complexes $[22,23]$. The structure of $4^{\prime}$-Phtpy (1, Scheme 1) was first reported in 1990 [24] and a second report of the single-crystal structure appeared in 2007 [25]. However, in neither case was the crystal packing described.

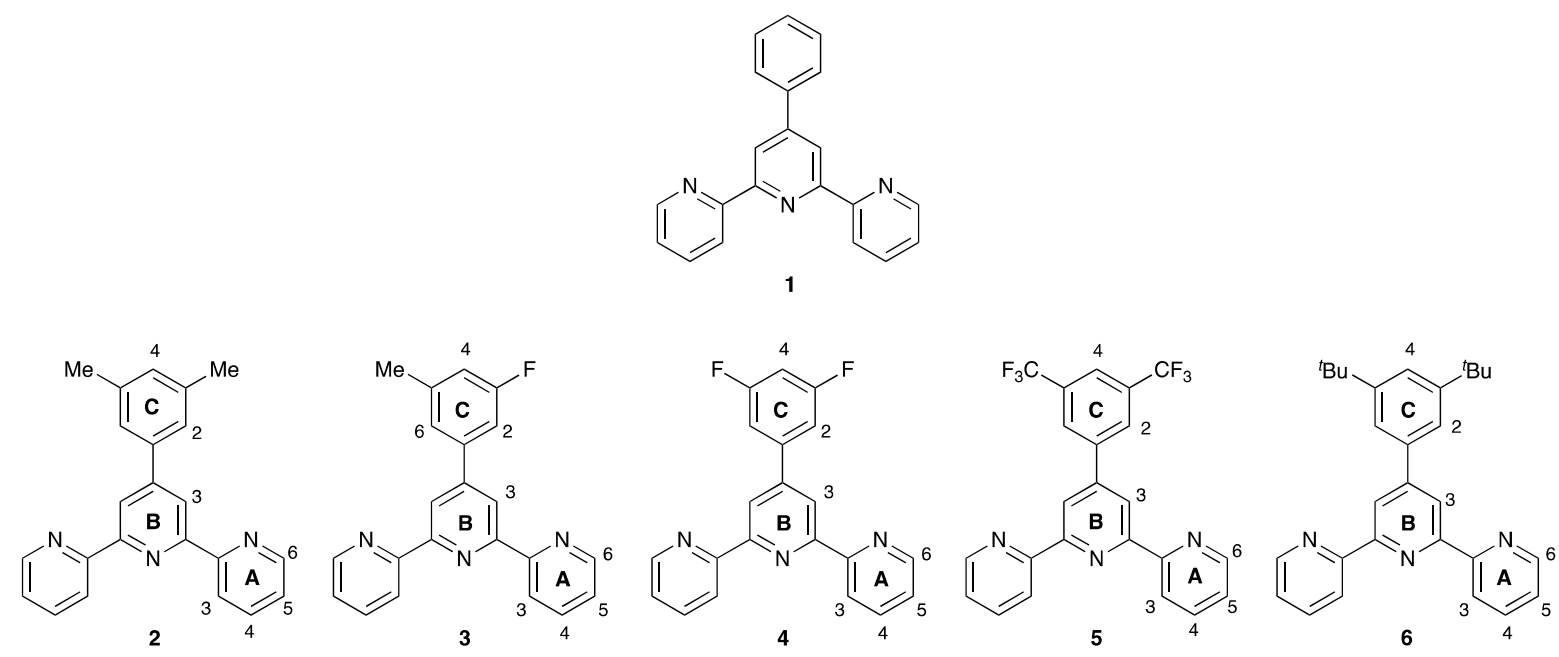

Scheme 1. Structures of the tpy ligands 1-6, with atom numbering in 2-6 for NMR spectroscopic assignments.

The replacement of hydrogen by fluorine has a significant effect on solid-state structural properties, the archetypal example being in benzene or hexafluorobenzene versus a 1:1 co-crystallized mixture of these compounds. In the crystal lattice, $\mathrm{C}_{6} \mathrm{H}_{6}$ [26] and $\mathrm{C}_{6} \mathrm{~F}_{6}$ [27] both show edge-to-face $\mathrm{CX} \ldots$ $\pi$-interactions $(\mathrm{X}=\mathrm{H}[6,7]$ or $\mathrm{F}[28])$, whereas $\pi$-stacking controls the assembly in a co-crystallized 1:1 mixture of $\mathrm{C}_{6} \mathrm{D}_{6}$ and $\mathrm{C}_{6} \mathrm{~F}_{6}[29,30]$. Hulliger and coworkers have provided valuable insight into phenyl...perfluorophenyl $\left(\pi_{\mathrm{H}} \ldots \pi_{\mathrm{F}}\right), \mathrm{CF} \ldots \mathrm{H}, \mathrm{F} \ldots \mathrm{F}, \mathrm{CF} \ldots \pi_{\mathrm{F}}$ and anion... $\pi_{\mathrm{F}}$ interactions in crystal packing $[31,32]$ and it has been concluded that hydrogen bonds are usually favored over $\pi_{\mathrm{H}} \ldots \pi_{\mathrm{F}}$ contacts [32].

We present here a series of new tpy compounds, 2-5 (Scheme 1) and the single crystal structures of $\mathbf{3}$ and 5 . The packing is compared with that in $\mathbf{1}$, and we discuss the effects of introducing $\mathrm{F}_{\text {or }} \mathrm{CF}_{3}$ in place of $\mathrm{H}$ in the 3- and 5-positions of the 4'-phenyl substituent. We also describe the single crystal structure of $6 \cdot \mathrm{EtOH}$. 


\section{Materials and Methods}

\subsection{General}

${ }^{1} \mathrm{H},{ }^{13} \mathrm{C}$ and ${ }^{31} \mathrm{P}$ NMR spectra were recorded on a Bruker Avance III-500 spectrometer (Bruker BioSpin AG, Fällanden, Switzerland) at $298 \mathrm{~K}$. The ${ }^{1} \mathrm{H}$ and ${ }^{13} \mathrm{C}$ NMR chemical shifts were referenced with respect to residual solvent peaks $(\delta$ TMS $=0)$. A Shimadzu LCMS-2020 instrument (Shimadzu Schweiz GmbH, Roemerstr. 3, 4153 Reinach, Switzerland) was used to record electrospray ionization (ESI) mass spectra and high-resolution ESI (HR-ESI) mass spectra were measured on a Bruker maXis 4G QTOF instrument (Bruker BioSpin AG, Fällanden, Switzerland). PerkinElmer UATR Two (Perkin Elmer, Bahnstrasse 8, 8603 Schwerzenbach, Switzerland) and Cary-5000 (Agilent Technologies Inc., Santa Clara, CA, United States) spectrometers were used to record FT-infrared (IR) and absorption spectra, respectively.

Compounds 1 and $\mathbf{6}$ were prepared by the one-pot method of Wang and Hanan [33], and the NMR spectroscopic data matched those previously reported [34].

\subsection{Compound 2}

3,5-Dimethylbenzaldehyde (1.0 g, $7.45 \mathrm{mmol})$ was dissolved in $\mathrm{EtOH}(50 \mathrm{~mL})$, then 2-acetylpyridine $(2.3 \mathrm{~g}, 18.6 \mathrm{mmol})$ and $\mathrm{KOH}(1.05 \mathrm{~g}, 18.6 \mathrm{mmol})$ were added to the solution. Aqueous $\mathrm{NH}_{3}(32 \%, 57.4 \mathrm{~mL})$ was slowly added to the reaction mixture and stirred at room temperature overnight. The solid that formed was collected by filtration, washed with water $(3 \times 10 \mathrm{~mL}), \mathrm{EtOH}(3 \times 10 \mathrm{~mL})$ and $\mathrm{Et}_{2} \mathrm{O}(3 \times 10 \mathrm{~mL})$ and dried in vacuo. Compound 2 was isolated as a colorless powder $(1.02 \mathrm{~g}, 3.023 \mathrm{mmol}, 40.6 \%)$. M.p. $=200.4{ }^{\circ} \mathrm{C} .{ }^{1} \mathrm{H} \mathrm{NMR}\left(500 \mathrm{MHz}, \mathrm{CDCl}_{3}\right)$ $\delta / \mathrm{ppm} 8.75\left(\mathrm{~m}, 2 \mathrm{H}, \mathrm{H}^{\mathrm{A} 6}\right), 8.71\left(\mathrm{~s}, 2 \mathrm{H}, \mathrm{H}^{\mathrm{B} 3}\right), 8.68\left(\mathrm{~d}, J=8.0 \mathrm{~Hz}, 2 \mathrm{H}, \mathrm{H}^{\mathrm{A} 3}\right), 7.88(\mathrm{td}, J=7.7,1.8 \mathrm{~Hz}$, $\left.2 \mathrm{H}, \mathrm{H}^{\mathrm{A} 4}\right), 7.53\left(\mathrm{~s}, 2 \mathrm{H}, \mathrm{H}^{\mathrm{C} 2}\right), 7.35\left(\mathrm{~m}, 2 \mathrm{H}, \mathrm{H}^{\mathrm{A} 5}\right), 7.09\left(\mathrm{~s}, 1 \mathrm{H}, \mathrm{H}^{\mathrm{C} 4}\right), 2.42\left(\mathrm{~s}, 6 \mathrm{H}, \mathrm{H}^{\mathrm{Me}}\right) .{ }^{13} \mathrm{C}\left\{{ }^{1} \mathrm{H}\right\} \mathrm{NMR}$ $\left(126 \mathrm{MHz}, \mathrm{CDCl}_{3}\right) \delta / \mathrm{ppm} 156.5\left(\mathrm{C}^{\mathrm{A} 2}\right), 155.9\left(\mathrm{C}^{\mathrm{B} 2}\right), 150.8\left(\mathrm{C}^{\mathrm{B} 4}\right), 149.3\left(\mathrm{C}^{\mathrm{A} 6}\right), 138.6\left(\mathrm{C}^{\mathrm{C} 3}\right), 138.5\left(\mathrm{C}^{\mathrm{C} 1}\right)$, $137.0\left(\mathrm{C}^{\mathrm{A} 4}\right), 130.8\left(\mathrm{C}^{\mathrm{C} 4}\right), 125.3\left(\mathrm{C}^{\mathrm{C} 2}\right), 123.9\left(\mathrm{C}^{\mathrm{A} 5}\right), 121.6\left(\mathrm{C}^{\mathrm{A} 3}\right), 119.1\left(\mathrm{C}^{\mathrm{B} 3}\right), 21.5\left(\mathrm{C}^{\mathrm{Me}}\right)$. UV-VIS $\left(\mathrm{CHCl}_{3}\right.$, $\left.2.5 \times 10^{-5} \mathrm{~mol} \mathrm{dm}{ }^{-3}\right) \lambda / \mathrm{nm} 255\left(\varepsilon / \mathrm{dm}^{3} \mathrm{~mol}^{-1} \mathrm{~cm}^{-1} 26,800\right), 280(33,000), 320$ (sh 6,300). IR $\bar{v} / \mathrm{cm}^{-1}$ $1582(\mathrm{~s}), 1469(\mathrm{~m}), 1384(\mathrm{~m}), 1040(\mathrm{~m}), 857(\mathrm{~s}), 788(\mathrm{~s}), 738(\mathrm{~s}), 658(\mathrm{~s}), 642$ (s), $623(\mathrm{~m})$. ESI-MS m/z 338.1 $[\mathrm{M}+\mathrm{H}]^{+}$(calc. 338.2). HR ESI-MS $m / z 338.1655[\mathrm{M}+\mathrm{H}]^{+}$(calc. 338.1652).

\subsection{Compound 3}

3-Fluoro-5-methylbenzaldehyde $(0.25 \mathrm{~g}, 1.81 \mathrm{mmol})$ was dissolved in $\mathrm{EtOH}(50 \mathrm{~mL})$, then 2-acetylpyridine $(0.56 \mathrm{~g}, 4.52 \mathrm{mmol})$ and $\mathrm{KOH}(0.25 \mathrm{~g}, 4.52 \mathrm{mmol})$ were added to the solution. Aqueous $\mathrm{NH}_{3}(32 \%, 14 \mathrm{~mL})$ was slowly added to the reaction mixture, which was then stirred at room temperature overnight. The solid that formed was collected by filtration, washed with water $(3 \times 10 \mathrm{~mL}), \mathrm{EtOH}(3 \times 10 \mathrm{~mL})$ and $\mathrm{Et}_{2} \mathrm{O}(3 \times 10 \mathrm{~mL})$ and dried in vacuo. Compound 3 was isolated as a colorless powder $(0.28 \mathrm{~g}, 0.82 \mathrm{mmol}, 45.3 \%)$. M.p. $=181.9{ }^{\circ} \mathrm{C} .{ }^{1} \mathrm{H} \mathrm{NMR}\left(500 \mathrm{MHz}, \mathrm{CDCl}_{3}\right) \delta / \mathrm{ppm} 8.74$ $\left(\mathrm{ddd}, J=4.8,1.8,0.9 \mathrm{~Hz}, 2 \mathrm{H}, \mathrm{H}^{\mathrm{A} 6}\right), 8.69\left(\mathrm{~s}, 2 \mathrm{H}, \mathrm{H}^{\mathrm{B} 3}\right), 8.67\left(\mathrm{dt}, J=8.0,1.1 \mathrm{~Hz}, 2 \mathrm{H}, \mathrm{H}^{\mathrm{A} 3}\right), 7.89(\mathrm{td}, J=7.7$, $\left.1.8 \mathrm{~Hz}, 2 \mathrm{H}, \mathrm{H}^{\mathrm{A} 4}\right), 7.50\left(\mathrm{t}, J=0.8 \mathrm{~Hz}, 1 \mathrm{H}, \mathrm{H}^{\mathrm{C} 6}\right), 7.41\left(\mathrm{~m}, 1 \mathrm{H}, \mathrm{H}^{\mathrm{C} 2}\right), 7.36\left(\mathrm{ddd}, J=7.5,4.8,1.2 \mathrm{~Hz}, 2 \mathrm{H}, \mathrm{H}^{\mathrm{A} 5}\right)$, $6.97\left(\mathrm{~m}, 1 \mathrm{H}, \mathrm{H}^{\mathrm{C} 4}\right), 2.46\left(\mathrm{~s}, 3 \mathrm{H}, \mathrm{H}^{\mathrm{CH} 3}\right) .{ }^{13} \mathrm{C}\left\{{ }^{1} \mathrm{H}\right\} \mathrm{NMR}\left(126 \mathrm{MHz}, \mathrm{CDCl}_{3}\right) \delta / \mathrm{ppm} 163.4(\mathrm{~d}, J=245 \mathrm{~Hz}$, $\left.\mathrm{C}^{\mathrm{C} 3}\right), 156.25\left(\mathrm{C}^{\mathrm{A} 2 / \mathrm{B} 2}\right), 156.2\left(\mathrm{C}^{\mathrm{A} 2 / \mathrm{B} 2}\right), 149.5\left(\mathrm{~d}, J_{\mathrm{CF}}=2.5 \mathrm{~Hz}, \mathrm{C}^{\mathrm{B} 4}\right), 149.3\left(\mathrm{C}^{\mathrm{A} 6}\right), 141.1(\mathrm{~d}, J=8.1 \mathrm{~Hz}$, $\left.\mathrm{C}^{\mathrm{C} 5}\right), 140.5\left(\mathrm{~d}, J=8.3 \mathrm{~Hz}, \mathrm{C}^{\mathrm{C} 1}\right), 137.1\left(\mathrm{C}^{\mathrm{A} 4}\right), 124.1\left(\mathrm{C}^{\mathrm{A} 5}\right), 123.9\left(\mathrm{~d}, J_{\mathrm{CF}}=2.5 \mathrm{~Hz}, \mathrm{C}^{\mathrm{C} 6}\right), 121.5\left(\mathrm{C}^{\mathrm{A} 3}\right), 119.0$ $\left(\mathrm{C}^{\mathrm{B} 3}\right), 116.6\left(\mathrm{~d}, J_{\mathrm{CF}}=21.0 \mathrm{~Hz}, \mathrm{C}^{\mathrm{C} 4}\right), 111.5\left(\mathrm{~d}, J_{\mathrm{CF}}=22.5 \mathrm{~Hz}, \mathrm{C}^{\mathrm{C} 2}\right), 21.6\left(\mathrm{~d}, J_{\mathrm{CF}}=1.9 \mathrm{~Hz}, \mathrm{C}^{\mathrm{CH} 3}\right) .{ }^{19} \mathrm{~F} \mathrm{NMR}$

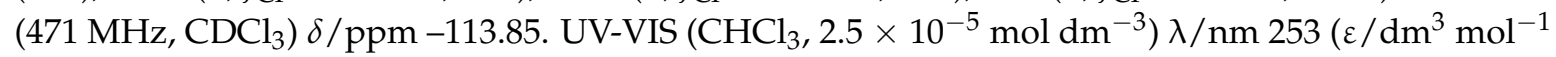
$\mathrm{cm}^{-1}$ 30,550), 278 (29,230), 317 (sh 6,900). IR $\bar{v} / \mathrm{cm}^{-1} 2919(\mathrm{w}), 1582(\mathrm{~m}), 1470(\mathrm{~m}), 1385(\mathrm{~m}), 1290(\mathrm{w})$, $1146(\mathrm{~m}), 965(\mathrm{~m}), 857(\mathrm{~m}), 788(\mathrm{~s}), 737$ (s), $658(\mathrm{~s}), 647(\mathrm{~s}), 502(\mathrm{w})$. ESI-MS m/z $342.1[\mathrm{M}+\mathrm{H}]^{+}$(calc. 342.1). HR ESI-MS m/z $342.1404[\mathrm{M}+\mathrm{H}]^{+}$(calc. 342.1401), $364.1223[\mathrm{M}+\mathrm{Na}]^{+}$(calc. 364.1220). 


\subsection{Compound 4}

3,5-Difluorobenzaldehyde $(1.00 \mathrm{~g}, 7.04 \mathrm{mmol})$ was dissolved in EtOH $(50 \mathrm{~mL})$, then 2-acetylpyridine $(2.18 \mathrm{~g}, 17.6 \mathrm{mmol})$ and $\mathrm{KOH}(0.99 \mathrm{~g}, 17.6 \mathrm{mmol})$ were added to the solution. Aqueous $\mathrm{NH}_{3}(32 \%, 54 \mathrm{~mL})$ was slowly added to the reaction mixture. This was stirred at room temperature overnight. The solid that formed was collected by filtration, washed with water $(3 \times 10 \mathrm{~mL}), \mathrm{EtOH}(3 \times 10 \mathrm{~mL})$ and $\mathrm{Et}_{2} \mathrm{O}(3 \times 10 \mathrm{~mL})$ and dried in vacuo. Compound 4 was isolated as a colorless powder $(1.08 \mathrm{~g}, 3.127 \mathrm{mmol}, 44.4 \%)$. M.p. $=179.8^{\circ} \mathrm{C} .{ }^{1} \mathrm{H} \mathrm{NMR}\left(500 \mathrm{MHz}, \mathrm{CDCl}_{3}\right) \delta / \mathrm{ppm}$ $8.73\left(\mathrm{~m}, 2 \mathrm{H}, \mathrm{H}^{\mathrm{A} 6}\right), 8.68\left(\mathrm{~s}, 2 \mathrm{H}, \mathrm{H}^{\mathrm{B} 3}\right), 8.68-8.65$ (overlapping $\left.\mathrm{m}, 2 \mathrm{H}, \mathrm{H}^{\mathrm{A} 3}\right), 7.89\left(\mathrm{~m}, 2 \mathrm{H}, \mathrm{H}^{\mathrm{A} 4}\right), 7.43(\mathrm{~m}, 2 \mathrm{H}$, $\left.\left.\mathrm{H}^{\mathrm{C} 2}\right), 7.37\left(\mathrm{~m}, 2 \mathrm{H}, \mathrm{H}^{\mathrm{A} 5}\right), 6.90\left(\mathrm{tt}, J_{\mathrm{FH}}=8.8, J_{\mathrm{HH}}=2.4 \mathrm{~Hz}, 1 \mathrm{H}, \mathrm{H}^{\mathrm{C} 4}\right) .{ }^{13} \mathrm{C}^{1} \mathrm{H}\right\} \mathrm{NMR}\left(126 \mathrm{MHz}, \mathrm{CDCl}_{3}\right)$ $\delta / \mathrm{ppm} 163.6\left(\mathrm{dd}, J_{\mathrm{FC}}=248.9,12.8 \mathrm{~Hz}, \mathrm{C}^{\mathrm{C} 3}\right), 156.4\left(\mathrm{C}^{\mathrm{B} 1}\right), 155.9\left(\mathrm{C}^{\mathrm{A} 2}\right), 149.3\left(\mathrm{C}^{\mathrm{A} 6}\right), 148.2(\mathrm{~d}, J=2.5 \mathrm{~Hz}$, $\left.\mathrm{C}^{\mathrm{B} 4}\right), 142.1\left(\mathrm{t}, J=9.5 \mathrm{~Hz}, \mathrm{C}^{\mathrm{C} 1}\right), 137 .\left(\mathrm{C}^{\mathrm{A} 4}\right), 124.2\left(\mathrm{C}^{\mathrm{A} 5}\right), 121.5\left(\mathrm{C}^{\mathrm{A} 3}\right), 118.8\left(\mathrm{C}^{\mathrm{B} 3}\right), 110.5\left(\mathrm{dd}, J_{\mathrm{FC}}=26.1\right.$, $\left.13.6 \mathrm{~Hz}, \mathrm{C}^{\mathrm{C} 2}\right), 104.4\left(\mathrm{t}, J_{\mathrm{FC}}=25.3 \mathrm{~Hz}, \mathrm{C}^{\mathrm{C} 4}\right) .{ }^{19} \mathrm{~F} \mathrm{NMR}\left(471 \mathrm{MHz}, \mathrm{CDCl}_{3}\right) \delta / \mathrm{ppm}-109.0$. UV-VIS $\left(\mathrm{CHCl}_{3}\right.$, $\left.2.5 \times 10^{-5} \mathrm{~mol} \mathrm{dm}{ }^{-3}\right) \lambda / \mathrm{nm} 251\left(\varepsilon / \mathrm{dm}^{3} \mathrm{~mol}^{-1} \mathrm{~cm}^{-1} 30,800\right), 277(24,650), 316(7,000) . \mathrm{IR} \bar{v} / \mathrm{cm}^{-1}$ $3093(\mathrm{w}), 1627(\mathrm{~m}), 1585(\mathrm{~s}), 1548(\mathrm{~m}), 1471(\mathrm{~m}), 1390(\mathrm{~s}), 1304(\mathrm{~m}), 1189(\mathrm{w}), 1118(\mathrm{~s}), 987(\mathrm{~s}), 857(\mathrm{~m})$, $740(\mathrm{~m}), 786$ (s), 730 (s), 659 (s), 640 (m), 509 (m). ESI-MS m/z $346.1[\mathrm{M}+\mathrm{H}]^{+}$(calc. 346.1). HR ESI-MS $\mathrm{m} / \mathrm{z} 346.1151[\mathrm{M}+\mathrm{H}]^{+}$(calc. 346.1150), 368.0970, [M+Na] ${ }^{+}$(calc. 368.0970).

\subsection{Compound 5}

3,5-Bis(trifluoromethyl)benzaldehyde $(1.0 \mathrm{~g}$, $4.16 \mathrm{mmol})$ was dissolved in $\mathrm{EtOH}(50 \mathrm{~mL})$, then 2-acetylpyridine $(1.28 \mathrm{~g}, 10.3 \mathrm{mmol})$ and $\mathrm{KOH}(0.58 \mathrm{~g}, 10.3 \mathrm{mmol})$ were added to the solution. Aqueous $\mathrm{NH}_{3}(32 \%, 31.8 \mathrm{~mL})$ was slowly added to the reaction mixture and stirred at room temperature overnight. The solid that formed was collected by filtration, washed with water $(3 \times 10 \mathrm{~mL})$, $\mathrm{EtOH}(3 \times 10 \mathrm{~mL})$ and $\mathrm{Et}_{2} \mathrm{O}(3 \times 10 \mathrm{~mL})$ and dried in vacuo. Compound 5 was isolated as a colorless powder (0.79 g, $1.774 \mathrm{mmol}, 42.9 \%)$. M.p. $=215.5^{\circ} \mathrm{C} .{ }^{1} \mathrm{H}$ NMR $\left(500 \mathrm{MHz}, \mathrm{CDCl}_{3}\right) \delta / \mathrm{ppm} 8.76(\mathrm{~d}$, $\left.J=3.3 \mathrm{~Hz}, 2 \mathrm{H}, \mathrm{H}^{\mathrm{A} 6}\right), 8.74\left(\mathrm{~s}, 2 \mathrm{H}, \mathrm{H}^{\mathrm{B} 3}\right), 8.69\left(\mathrm{~s}, 2 \mathrm{H}, \mathrm{H}^{\mathrm{A} 3}\right), 8.30\left(\mathrm{~s}, 2 \mathrm{H}, \mathrm{H}^{\mathrm{C} 2}\right), 7.98\left(\mathrm{~s}, 1 \mathrm{H}, \mathrm{H}^{\mathrm{C} 4}\right), 7.92(\mathrm{~m}$, $\left.2 \mathrm{H}, \mathrm{H}^{\mathrm{A} 4}\right), 7.40\left(\mathrm{~m}, 2 \mathrm{H}, \mathrm{H}^{\mathrm{A} 5}\right) .{ }^{13} \mathrm{C}\left\{{ }^{1} \mathrm{H}\right\} \mathrm{NMR}\left(126 \mathrm{MHz}, \mathrm{CDCl}_{3}\right) \delta / \mathrm{ppm} 156.6\left(\mathrm{C}^{\mathrm{B} 2}\right), 155.6\left(\mathrm{C}^{\mathrm{A} 2}\right), 149.3$ $\left(\mathrm{C}^{\mathrm{A} 6}\right), 147.6\left(\mathrm{C}^{\mathrm{B} 4}\right), 141.1\left(\mathrm{C}^{\mathrm{C} 1}\right), 137.3\left(\mathrm{C}^{\mathrm{A} 4}\right), 132.6$ (quartet, $\left.J_{\mathrm{CF}}=33.6 \mathrm{~Hz}, \mathrm{C}^{\mathrm{C} 3}\right), 127.7\left(\mathrm{~m}, \mathrm{C}^{\mathrm{C} 2}\right), 124.5$ $\left(\mathrm{C}^{\mathrm{A} 5}\right), 123.4$ (quartet, $\left.J_{\mathrm{CF}}=273 \mathrm{~Hz}, \mathrm{C}^{\mathrm{CF} 3}\right), 122.8\left(\mathrm{~m}, \mathrm{C}^{\mathrm{C} 4}\right), 121.7\left(\mathrm{C}^{\mathrm{A} 3}\right), 119.0\left(\mathrm{C}^{\mathrm{B} 3}\right) .{ }^{19} \mathrm{~F}$ NMR $(471 \mathrm{MHz}$, $\left.\mathrm{CDCl}_{3}\right) \delta / \mathrm{ppm}-62.7$. UV-VIS $\left(\mathrm{CHCl}_{3}, 2.5 \times 10^{-5} \mathrm{~mol} \mathrm{dm}^{-3}\right) \lambda / \mathrm{nm} 246\left(\varepsilon / \mathrm{dm}^{3} \mathrm{~mol}^{-1} \mathrm{~cm}^{-1} 39,240\right)$, $278(26,800), 316(8,900)$. IR $\bar{v} / \mathrm{cm}^{-1} 1582(\mathrm{~m}), 1568(\mathrm{~m}), 1385(\mathrm{~s}), 1333(\mathrm{~m}), 1276(\mathrm{~s}), 1187(\mathrm{~s}), 1170(\mathrm{~s})$, $1066(\mathrm{~s}), 882(\mathrm{~s}), 844(\mathrm{~m}), 790(\mathrm{~s}), 748(\mathrm{~m}), 682(\mathrm{~s}), 638$ (s), $622(\mathrm{~m})$. ESI-MS m/z $446.1[\mathrm{M}+\mathrm{H}]^{+}$(calc. 446.1). HR ESI-MS m/z $446.1093[\mathrm{M}+\mathrm{H}]^{+}$(calc. 446.1086), 468.0908 [M+Na] ${ }^{+}$(calc. 468.0906).

\subsection{Crystallography}

Single crystal data were collected on a Bruker APEX-II diffractometer (Bruker AXS GmbH, Karlsruhe, Germany); data reduction, solution and refinement used APEX2, SuperFlip and CRYSTALS or OLEX, respectively [35-38]. Structure analysis and ORTEP-style diagrams used Mercury v. $3.6[39,40]$.

Compound 3: $\mathrm{C}_{22} \mathrm{H}_{16} \mathrm{FN}_{3}, M=341.39$, colorless block, triclinic, space group $P-1, a=7.0119$ (6), $b=8.5434(8), c=14.3033(13) \AA, \alpha=96.629(4), \beta=99.336(4), \gamma=100.914(4)^{\circ}, U=820.71(13) \AA^{3}$, $\mathrm{Z}=2, D_{c}=1.381 \mathrm{Mg} \mathrm{m}^{-3}, \mu(\mathrm{Cu}-\mathrm{K} \alpha)=0.732 \mathrm{~mm}^{-1}, T=130 \mathrm{~K}$. Total 9291 reflections, 3019 unique, $R_{\text {int }}=0.031$. Refinement of 2775 reflections (235 parameters) with $I>2 \sigma(I)$ converged at final $R 1=0.0384(R 1$ all data $=0.0412), w R 2=0.0917(w R 2$ all data $=0.0938), g o f=0.8950$. CCDC 1886084.

Compound 5: $\mathrm{C}_{23} \mathrm{H}_{13} \mathrm{~F}_{6} \mathrm{~N}_{3}, M=445.36$, colorless block, monoclinic, space group $\mathrm{C} 2 / \mathrm{c}$, $a=29.974(3), b=7.4201(6), c=18.6949(16) \AA, \beta=110.595(4)^{\circ}, U=3892.2(6) \AA^{3}, Z=8, D_{c}=1.520$ $\mathrm{Mg} \mathrm{m}^{-3}, \mu(\mathrm{Cu}-\mathrm{K} \alpha)=1.148 \mathrm{~mm}^{-1}, T=130 \mathrm{~K}$. Total 20,893 reflections, 9917 unique, $R_{\text {int }}=0.0346$. Refinement of 3640 reflections (345 parameters) with $I>2 \sigma(I)$ converged at final $R 1=0.0885$ ( $R 1$ all data $=0.1003), w R 2=0.2370(w R 2$ all data $=0.2492)$, gof $=1.091$. CCDC 1886082. 
Compound 6. EtOH: $\mathrm{C}_{31} \mathrm{H}_{37} \mathrm{~N}_{3} \mathrm{O}, M=467.65$, colorless block, triclinic, space group $P-1$, $a=9.3471(8), b=9.9879(8), c=16.1334(13) \AA, \alpha=80.317(2), \beta=75.464(2), \gamma=66.816(2)^{\circ}, U=1336.15(11)$ $\AA^{3}, Z=2, D_{c}=1.162 \mathrm{Mg} \mathrm{m}^{-3}, \mu(\mathrm{Cu}-\mathrm{K} \alpha)=0.544 \mathrm{~mm}^{-1}, T=123 \mathrm{~K}$. Total 17522 reflections, 4797 unique, $R_{\text {int }}=0.022$. Refinement of 4688 reflections ( 292 parameters) with $I>2 \sigma(I)$ converged at final $R 1=0.0382$ $(R 1$ all data $=0.0388), w R 2=0.1009(w R 2$ all data $=0.1011)$, gof $=0.9753$. CCDC 1886083.

\section{Results and Discussion}

\subsection{Synthesis and Solution Characterization of Complexes}

Compounds 2-6 were prepared by the one-pot method of Wang and Hanan [33]. For 6, the spectroscopic data were in accord with those previously reported [34]. The syntheses of 2-5 are summarized in Scheme 2, and the compounds were isolated as white solids in between $40.6 \%$ and $45.3 \%$ yields. Electrospray mass spectra showed peak envelopes at $\mathrm{m} / \mathrm{z} 338.1$ for $2,342.1$ for 3 , 346.1 for 4 , and 446.1 for 5 assigned to the $[\mathrm{M}+\mathrm{H}]^{+}$ion. The assignments were further confirmed with high-resolution mass spectra (Figures S1-S4, in the Supplementary Materials) in which peaks for $[\mathrm{M}+\mathrm{H}]^{+}$were observed for all compounds, as well as $[\mathrm{M}+\mathrm{Na}]^{+}$for 3, 4 and 5.

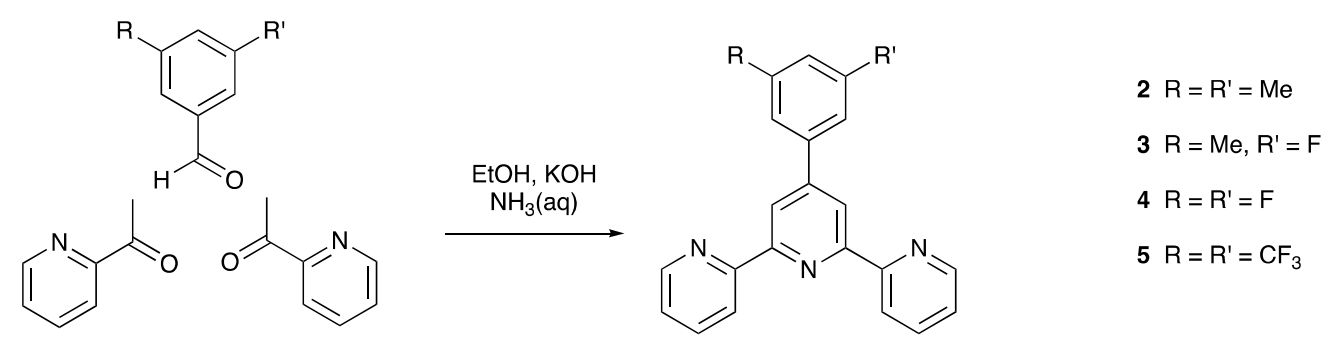

Scheme 2. One-pot synthetic approach to compounds 2-5.

The solution ${ }^{1} \mathrm{H}$ and ${ }^{13} \mathrm{C}$ NMR spectra of $\mathbf{2 - 5}$ were assigned using 2D methods (COSY, NOESY, HMQC and HMBC) and representative 1D and 2D spectra are shown in Figures S5-S17. The aromatic regions of the ${ }^{1} \mathrm{H}$ NMR spectra are shown in Figure 1. As expected, the signals for the tpy domains (rings A and B, see Scheme 1) do not change significantly upon the introduction of different substituents in the phenyl ring (ring C). A change from a 3,5-dimethylphenyl group in 2 to 3,5-bis(trifluoromethyl)phenyl in 5 shifts the signals for protons $\mathrm{H}^{\mathrm{C} 2}$ and $\mathrm{H}^{\mathrm{C} 4}$ to higher frequency. The ${ }^{1} \mathrm{H}$ NMR spectrum of 3 (Figure 1) is consistent with the lower symmetry of the 3-fluoro-5-methylphenyl substituent compared to the substituents in 2, 4 or 5, and the signals in the spectrum of 3 for $\mathrm{H}^{\mathrm{C} 4}$ and $\mathrm{H}^{\mathrm{C} 2}$ (both of which show coupling to ${ }^{19} \mathrm{~F}$ ) were distinguished by a NOESY cross-peak between the signals for $\mathrm{H}^{\mathrm{B} 3}$ and $\mathrm{H}^{\mathrm{C} 2}$ (Figure 2). The loss of the resonance for $\mathrm{H}^{\mathrm{C} 6}$ on going from 3 to 4 (Figure 1 ) is consistent with the change in symmetry on going from a 3-fluoro-5-methylphenyl to 3,5-difluorophenyl substituent. The ${ }^{13} \mathrm{C}\left\{{ }^{1} \mathrm{H}\right\}$ NMR spectra of 4 and 5 are shown in Figure 3 and Figure S15, respectively. In 4, nucleus $\mathrm{C}^{\mathrm{C} 3}$ is characterized by a doublet of doublets at $\delta 163.6 \mathrm{ppm}$ with values of ${ }^{1} J_{\mathrm{FC}}=248.9 \mathrm{~Hz}$ and ${ }^{4} J_{\mathrm{FC}}=12.8 \mathrm{~Hz}$ (Figure 3c), while signals for $\mathrm{C}^{\mathrm{C} 4}$ and $\mathrm{C}^{\mathrm{C} 2}$ appear as a triplet at $\delta 104.4 \mathrm{ppm}\left({ }^{2} J_{\mathrm{FC}}=25.3 \mathrm{~Hz}\right)$ and a doublet of doublets at $\delta$ $110.5 \mathrm{ppm}\left({ }^{2} J_{\mathrm{FC}}=26.1 \mathrm{~Hz}\right.$ and $\left.{ }^{4} J_{\mathrm{FC}}=13.6 \mathrm{~Hz}\right)$, respectively (Figure $\left.3 \mathrm{~b}\right)$. In 5 , the signal for $\mathrm{C}^{\mathrm{C} 3}$ is a quartet $\left({ }^{2} J_{\mathrm{FC}}=33.6 \mathrm{~Hz}\right)$, and the quartet for the $\mathrm{CF}_{3}$ group has ${ }^{1} J_{\mathrm{FC}}=273 \mathrm{~Hz}$ (Figure S15). 


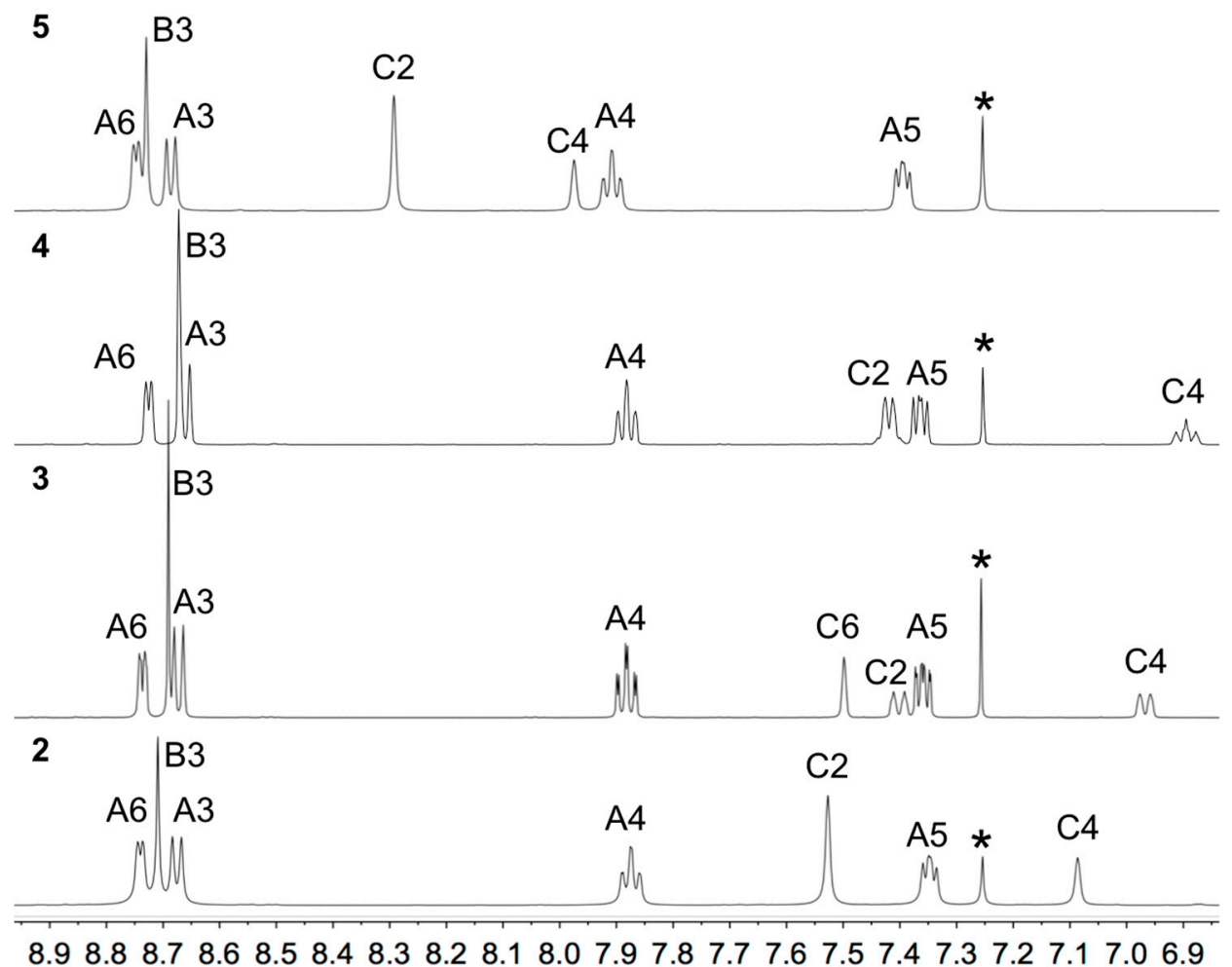

Figure 1. Aromatic regions of the ${ }^{1} \mathrm{H}$ NMR spectra $\left(500 \mathrm{MHz}, \mathrm{CDCl}_{3}\right.$ ) of compounds 2-5 with atom labeling as shown in Scheme $1 .{ }^{*}=$ residual $\mathrm{CHCl}_{3}$. Chemical shifts in $\delta / \mathrm{ppm}$.

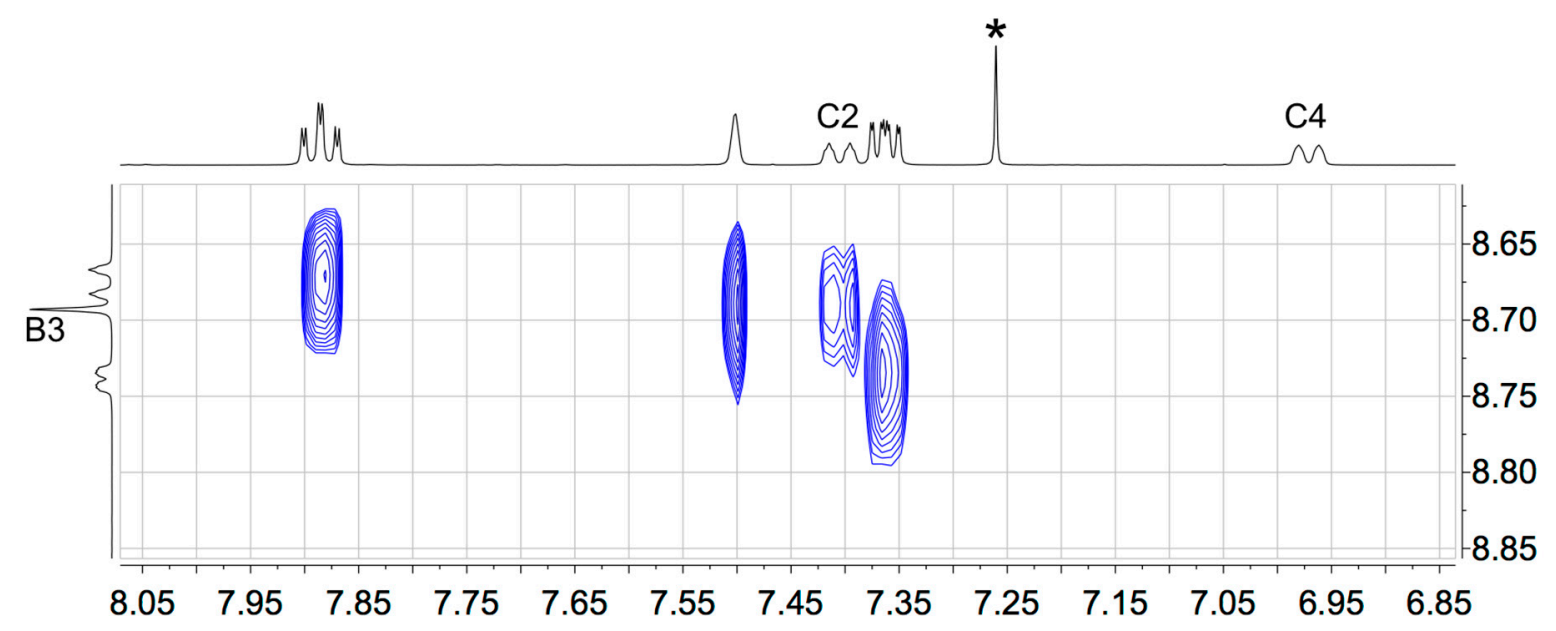

Figure 2. Part of the NOESY spectrum of compound 3, showing the cross-peak between the signals for $\mathrm{H}^{\mathrm{B} 3}$ and $\mathrm{H}^{\mathrm{C} 2}$. 
(c) (b)

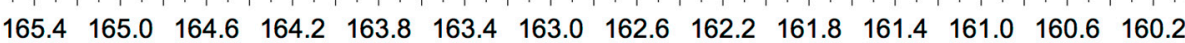

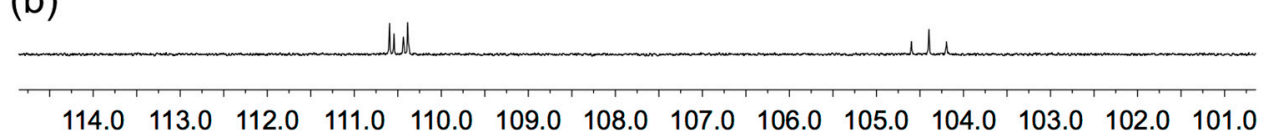

(a)

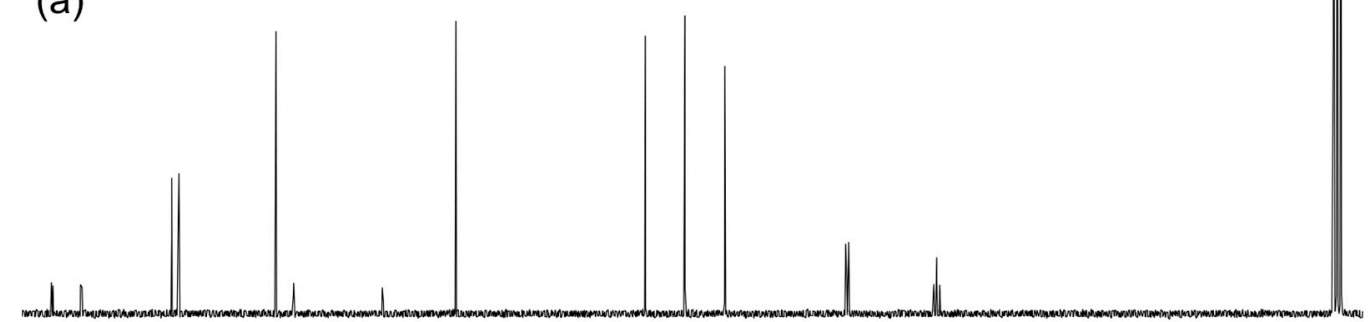

$\begin{array}{llllllllllllllllll}165 & 160 & 155 & 150 & 145 & 140 & 135 & 130 & 125 & 120 & 115 & 110 & 105 & 100 & 95 & 90 & 85 & 80\end{array}$

Figure 3. ${ }^{13} \mathrm{C}\left\{{ }^{1} \mathrm{H}\right\} \mathrm{NMR}$ spectrum $\left(126 \mathrm{MHz}, \mathrm{CDCl}_{3}\right)$ of compound 4. (a) Full spectrum with solvent reference, ${ }^{*}=\mathrm{CDCl}_{3}$. (b) Expansion of the signals for nuclei $\mathrm{C}^{\mathrm{C} 2}$ and $\mathrm{C}^{\mathrm{C}}$. (c) Expansion of the signal for $\mathrm{C}^{\mathrm{C} 3}$. Chemical shifts in $\delta / \mathrm{ppm}$.

Figure 4 displays the solution absorption spectra of compounds 2-5. The absorptions are assigned to spin-allowed $\pi^{*} \leftarrow \pi$ transitions in 2, and to $\pi^{*} \leftarrow \pi$ and $\pi^{*} \leftarrow \mathrm{n}$ transitions in 3, 4 and 5. On going from 2 to 3 to 4, the change from 3,5-dimethylphenyl to 3-fluoro-5-methylphenyl to 3,5-difluorophenyl substituent leads to a dominance of the highest energy absorption around $253 \mathrm{~nm}$ and a decrease in intensity of the absorption around $280 \mathrm{~nm}$. This trend is particularly noticeable upon introducing the trifluoromethyl groups in compound 5.

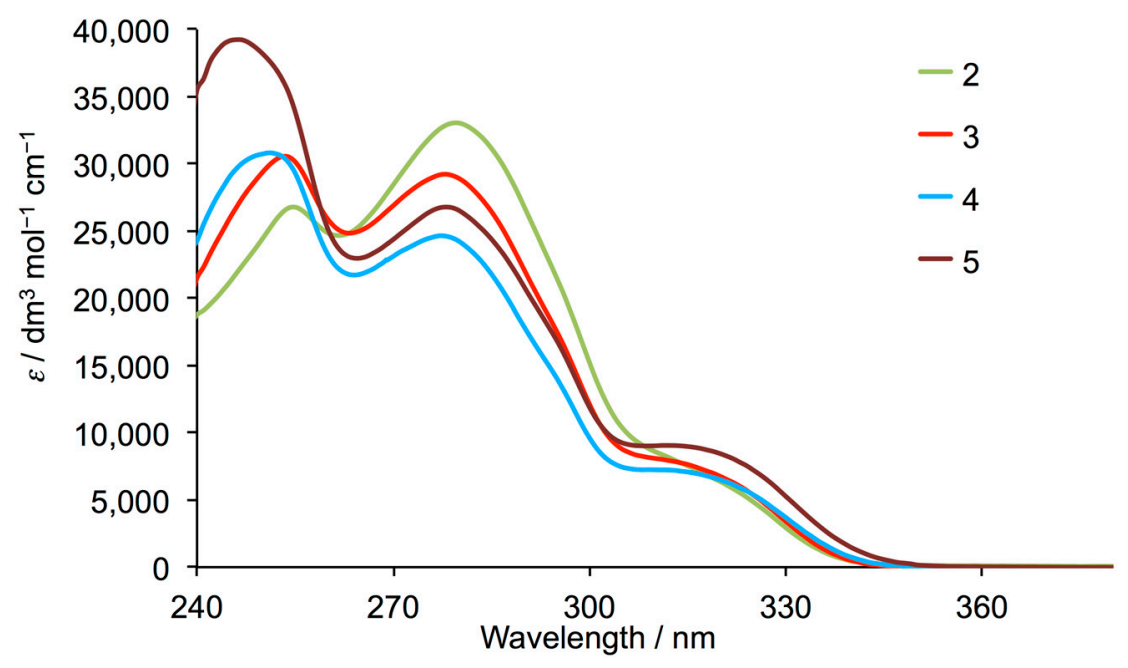

Figure 4. Solution absorption spectra of $2-5\left(\mathrm{CHCl}_{3}, 2.5 \times 10^{-5} \mathrm{~mol} \mathrm{dm}^{-3}\right)$.

\subsection{Single Crystal Structures of 3,5 and 6}

Compounds 2-6 were recrystallized from a hot mixture of chloroform and ethanol. Upon cooling the solutions, X-ray quality single crystals of 3,5 and $\mathbf{6} \cdot \mathrm{EtOH}$ were obtained. Compounds 3 and $\mathbf{6} \cdot \mathrm{EtOH}$ crystallize in the triclinic space group $P-1$, while 5 crystallizes in the monoclinic space group 
$C 2 / c$. The molecular structures of $3, \mathbf{5}$ and $\mathbf{6}$ are shown in Figures $5-7$ and selected bond distances and angles are given in the figure captions. Each $\mathrm{CF}_{3}$ group in $\mathbf{5}$ is rotationally disordered, and each fluorine atom has been modeled over two sites of partial occupancies $0.532(8)$ and $0.468(8)$ for the $\mathrm{F}$ atoms bonded to C23, and 0.598(10) and 0.402(10) for the F atoms bonded to C22. Only the major occupancy sites are used in the discussion below. As expected, the tpy unit in each of 3,5 and $\mathbf{6}$ adopts a trans,trans-configuration. The dihedral angles between pairs of bonded pyridine rings are $22.7^{\circ}$ and $4.4^{\circ}$ in $3,6.2^{\circ}$ and $6.1^{\circ}$ in 5 , and $21.4^{\circ}$ and $3.5^{\circ}$ in 6 . These values compare with $5.7^{\circ}$ in the parent compound 1 for which the asymmetric unit contains half-the molecule and the second half is generated by a $C_{2}$ axis in the orthorhombic space group Pbcn [24]. The $4^{\prime}$-phenyl ring in each of 3 , 5 and $\mathbf{6}$ is twisted with respect to the central pyridine ring with the angle between the ring-planes being $28.2^{\circ}$ in $3,20.4^{\circ}$ in 5 , and $40.5^{\circ}$ in 6 . These values are noticeably larger than the $10.9^{\circ}$ observed in 1 [24]. Deviation from planarity is anticipated since it relieves close H...H interactions between pyridine and phenyl rings. The variation in twist angle is associated with different packing interactions (see Section 3.3).

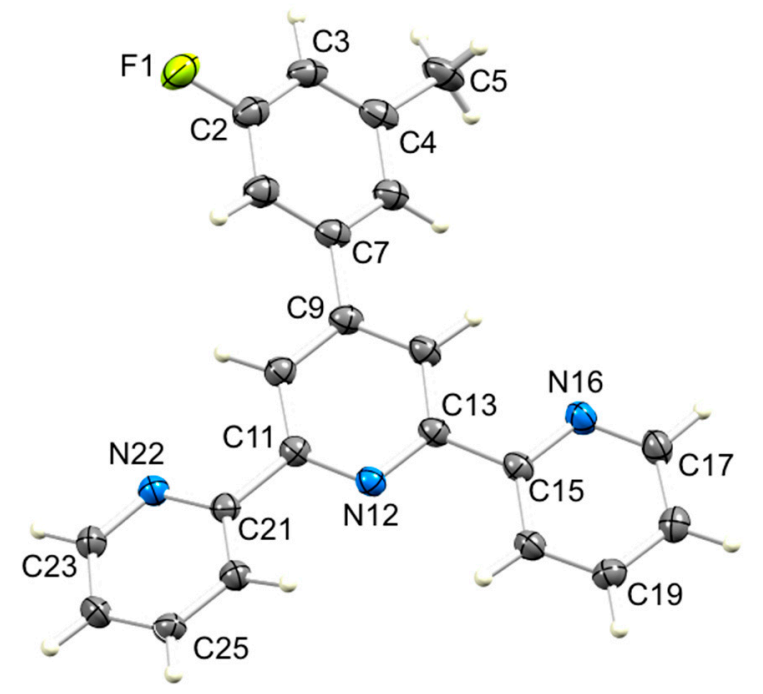

Figure 5. ORTEP-style diagram of molecule 3 with ellipsoids plotted at 50\% probability level. Selected bond parameters: F1-C2 = 1.3686(17), C4-C5 = 1.509(2), C7-C9 = 1.4945(18), C11-N12 = 1.3417(17), N12-C13 = 1.3407(17), C15-N16 = 1.3438(17), N16-C17 = 1.3347(18), C21-N22 = 1.3463(17), $\mathrm{N} 22-\mathrm{C} 23=1.3352(18) \AA$; $\mathrm{C} 11-\mathrm{N} 12-\mathrm{C} 13=117.29(11), \mathrm{C} 15-\mathrm{N} 16-\mathrm{C} 17=117.58(12), \mathrm{C} 15-\mathrm{N} 16-\mathrm{C} 17=$ $117.58(12)^{\circ}$. 


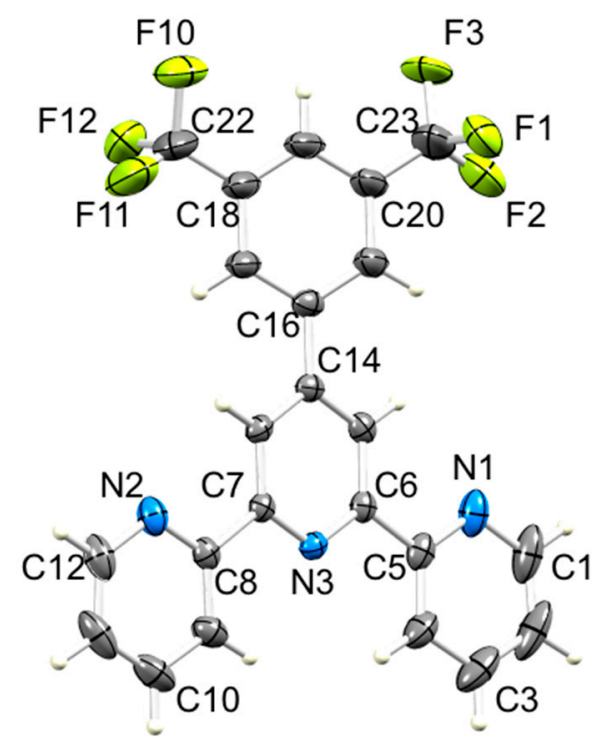

Figure 6. ORTEP-style diagram of molecule 5 with ellipsoids plotted at $40 \%$ probability level. Only the major occupancy F sites are shown (see text). Selected bond parameters: N1-C1 = 1.337(5), N1-C5 = 1.344(4), N2-C8 = 1.336(4), N2-C12 = 1.344(4), N3-C6 = 1.344(4), N3-C7 = 1.339(3), C23-F1 = 1.458(6), $\mathrm{C} 23-\mathrm{F} 2=1.309(7), \mathrm{C} 23-\mathrm{F} 3=1.321(6), \mathrm{C} 22-\mathrm{F} 10=1.337(6), \mathrm{C} 22-\mathrm{F} 11=1.310(6), \mathrm{C} 22-\mathrm{F} 12=1.436(6) \AA$; $\mathrm{C} 1-\mathrm{N} 1-\mathrm{C} 5=117.0(2), \mathrm{C} 8-\mathrm{N} 2-\mathrm{C} 12=117.34(18), \mathrm{C} 7-\mathrm{N} 3-\mathrm{C} 6=118.21(13)^{\circ}$.

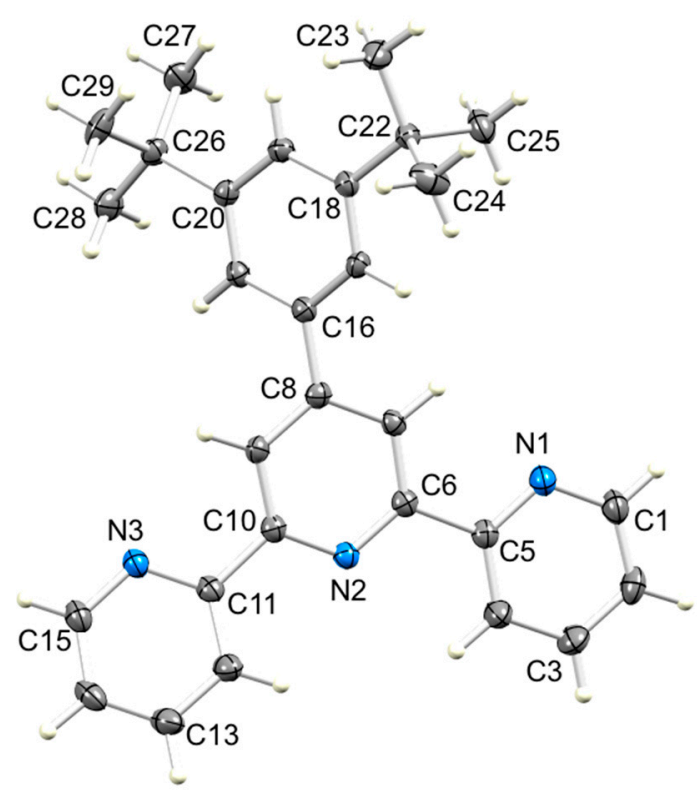

Figure 7. ORTEP-style diagram of molecule $\mathbf{6}$ in the solvated compound $\mathbf{6} \cdot \mathrm{EtOH}$ with ellipsoids plotted at $50 \%$ probability level. Selected bond parameters: N1-C1 $=1.3391(12), \mathrm{N} 1-\mathrm{C} 5=1.3418(10)$, $\mathrm{N} 2-\mathrm{C} 6=1.3409(10), \quad \mathrm{N} 2-\mathrm{C} 10=1.3421(10), \quad \mathrm{N} 3-\mathrm{C} 11=1.3478(11), \quad \mathrm{N} 3-\mathrm{C} 15=1.3380(11)$, $\mathrm{C} 8-\mathrm{C} 16=1.4877(14), \mathrm{C} 18-\mathrm{C} 22=1.5391(14), \mathrm{C} 20-\mathrm{C} 26=1.5365(14) \AA ; \mathrm{C} 1-\mathrm{N} 1-\mathrm{C} 5=117.40(7)$, $\mathrm{C} 6-\mathrm{N} 2-\mathrm{C} 10=117.51(6), \mathrm{C} 11-\mathrm{N} 3-\mathrm{C} 15=117.56(7)^{\circ}$.

In 6. EtOH, a molecule of $\mathrm{EtOH}$ is held within a pocket between a pyridine ring and tert-butyl group (Figure 8a) with hydrogen-bonded contacts of N3 ... H1-O100 $=2.08 \AA$ and $\mathrm{O} 100 \ldots \mathrm{H} 21^{\mathrm{i}}-\mathrm{C} 2^{\mathrm{i}}$ $=2.46 \AA\left(\mathrm{N} 3 \ldots \mathrm{O} 100=2.919(1) \AA, \mathrm{O} 100 \ldots \mathrm{C} 2^{\mathrm{i}}=3.257(1) \AA\right)$. As Figure $8 \mathrm{~b}$ shows, the interaction is extended by symmetry to give centrosymmetric pairs of molecules with two rings of each tpy unit stacked over one another. However, as can be judged from the similar values of the distance between the centroid of the ring with $\mathrm{N} 2$ to the plane of the ring with $\mathrm{N} 1^{\mathrm{i}}(3.61 \AA)$ and the inter-centroid 
separation (3.62 $\AA$ ), the rings are not offset as is required for an optimal face-to-face $\pi$-stacking interaction [21]. The angle between the planes of the rings containing $\mathrm{N} 2$ and $\mathrm{N} 1^{\mathrm{i}}$ is $3.5^{\circ}$.

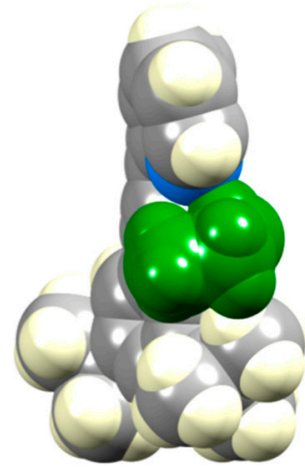

(a)

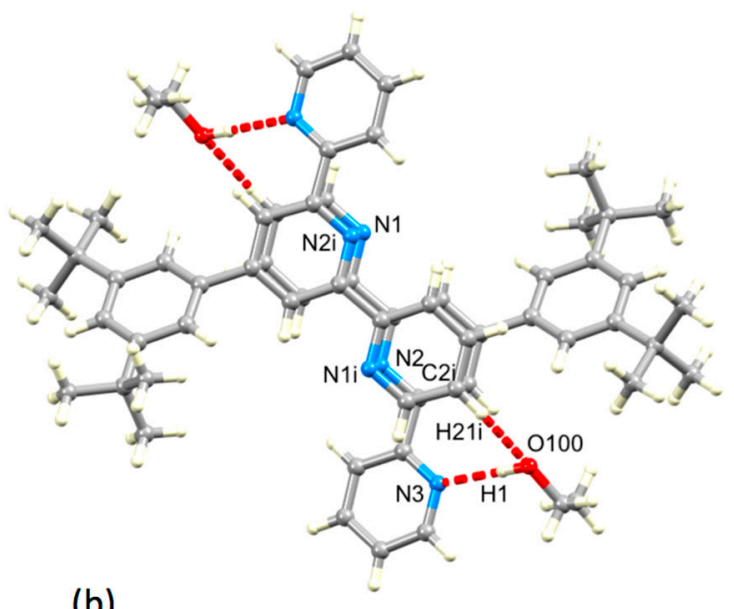

(b)

Figure 8. (a) A molecule of EtOH (shown in green) resides in a cavity in 6. EtOH. (b) Hydrogen-bonded interactions between $\mathbf{6}$ and $\mathrm{EtOH}$ molecules in $\mathbf{6} \cdot \mathrm{EtOH}$, and associated stacking of tpy units (see text). Symmetry code $\mathrm{i}=1-x, 1-y, 1-z$.

\subsection{Comparison of Packing Interactions in 1, 3, 5 and $\mathbf{6}$}

Crystal packing in $4^{\prime}$-phenyl-2, $2^{\prime}: 6^{\prime}, 2^{\prime \prime}$-terpyridine, $\mathbf{1}$, has not previously been discussed, although two entries of the single crystal structure (refcodes SIXLAM [24] and SIXLAM01 [25]) appear in the Cambridge Structural Database (CSD, v. 5.40, November 2018 [41]). In order to assess the role of the $4^{\prime}$-(3,5-substituted) phenyl group, it is instructive to first examine the crystal packing in $\mathbf{1}$ using data from SIXLAM [24]. Figure 9a shows that the almost planar molecules are arranged in ribbon-like assemblies that slice obliquely through the unit cell. The ribbons form herringbone assemblies, which nest next to one another. The arrangement of molecules in adjacent ribbons is displayed in Figure $9 \mathrm{~b}, \mathrm{c}$. Although the planes of the pyridine rings containing $\mathrm{N} 1$ and $\mathrm{N} 1^{\mathrm{i}}$ are $3.56 \AA$ apart, the slippage of the rings leads to non-optimal face-to-face $\pi$-stacking [21]. The same is true of any possible $\pi$-interaction between the rings containing $\mathrm{N} 2$ and $\mathrm{N} 1^{\mathrm{i}}$. The phenyl ring is not involved in face-to-face $\pi$-stacking.

Both $\mathbf{1}$ and $\mathbf{3}$ crystallize without lattice solvent, and we can therefore directly assess the effects of introducing the 3-fluoro-5-methylphenyl group in place of a phenyl ring. The herringbone assembly in $\mathbf{1}$ is replaced by a layer-like packing (Figure S18), which arises through a combination of face-to-face $\pi$-stacking of aromatic rings and N ... H-C hydrogen bonding. Centrosymmetric pairs of molecules of 3 associate through hydrogen bonding or $\pi$-stacking of the 3-fluoro-5-methylphenyl substituents (Figure 10a). Hydrogen bonding involves one of the outer pyridine rings $\left(\mathrm{N} 16 \ldots \mathrm{H} 171^{\mathrm{i}}=2.61 \AA\right.$, $\mathrm{N} 16 \ldots \mathrm{H} 171^{\mathrm{i}}-\mathrm{C} 17^{\mathrm{i}}=146^{\circ}$, symmetry code $\left.\mathrm{i}=-x,-1-y, 1-z\right)$. Face-to-face $\pi$-stacking contacts between phenyl rings containing $\mathrm{C} 7$ and $\mathrm{C} 7^{\mathrm{ii}}$ (symmetry code $\mathrm{i}=1-x,-y, 2-z$ ) are characterized by a separation of the ring planes of $3.47 \AA$ and a ring centroid separation of $4.08 \AA$. Together, these interactions lead to the assembly of chains of molecules running through the lattice. The chains associate through $\pi$-stacking tpy domains. Centrosymmetric pairs of bipyridine units containing $\mathrm{N} 12 / \mathrm{N} 16^{\mathrm{iii}}$ and N16/N12 ${ }^{\mathrm{iii}}$ (symmetry code iii $=-x,-y, 1-z$ ) stack as shown in Figure 10b with a centroid ... plane separation of $3.44 \AA$ and centroid ... centroid distance of $3.79 \AA$. 


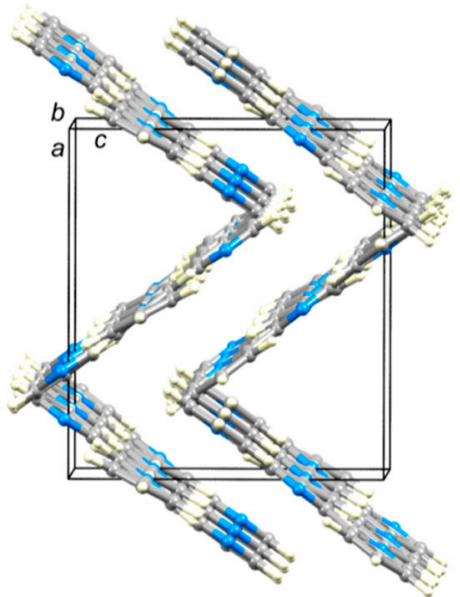

(a)

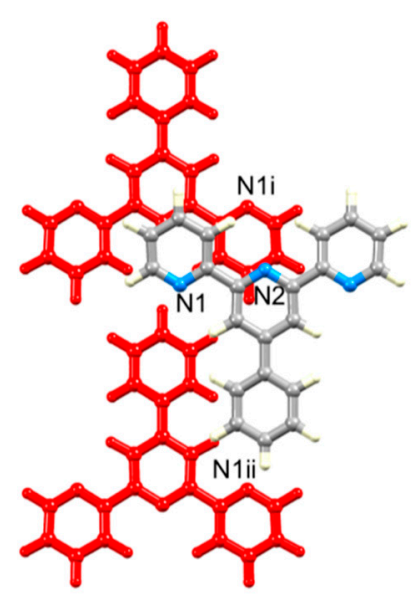

(b)

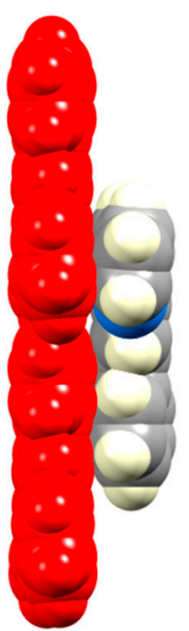

(c)

Figure 9. Packing of molecules in the crystal lattice of 1 (refcode SIXLAM [24,41]). (a) Molecules assemble into ribbons, which then stack in a herringbone manner. (b) Arrangement of molecules in adjacent ribbons; molecules colored red are in one ribbon, and the third molecule is in an adjacent ribbon. Symmetry code $\mathrm{i}=-x,-y, 1-z$. (c) Side view and space-filling representation of the three molecules are shown in $(\mathbf{b})$.

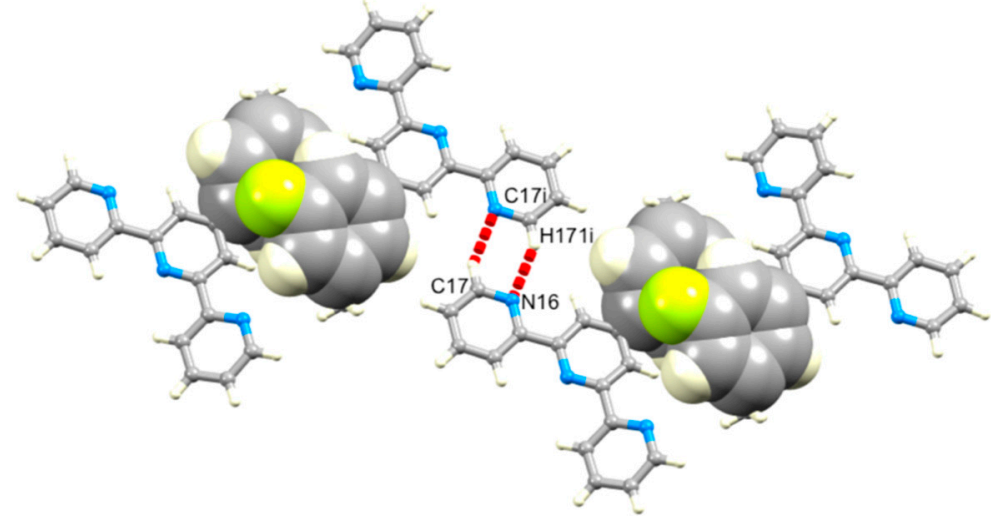

(a)

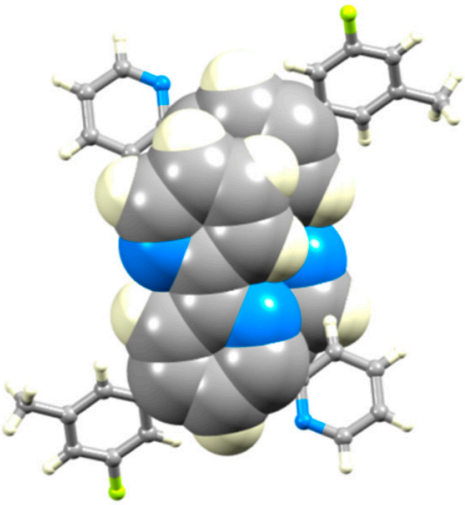

(b)

Figure 10. Packing interactions in 3. (a) Hydrogen bonding between pairs of pyridine rings and $\pi$-stacking of 3-fluoro-5-methylphenyl (symmetry code $\mathrm{i}=-x,-1-y, 1-z$ ), and (b) $\pi$-stacking of tpy domains.

Like 1 and 3, compound 5 crystallizes without solvent. On going from 3 to 5 , the N ... H-C hydrogen bonds between tpy units increase in number, involving both outer pyridine rings (Figure 11a). Comparison of Figures 10 and 11 show that the basic centrosymmetric hydrogen-bonded motif is replaced with a motif with $\mathrm{C} 2$ symmetry, while retaining the $\mathrm{N} \ldots \mathrm{H}-\mathrm{C}$ hydrogen bonds. In 5, the $\mathrm{N} 1 \ldots \mathrm{H} 1^{\mathrm{i}}$ and $\mathrm{N} 2 \ldots \mathrm{H} 12^{\mathrm{ii}}$ distances are 2.68 and $2.64 \AA$, and the $\mathrm{N} 1 \ldots \mathrm{H} 1^{\mathrm{i}}-\mathrm{C} 1^{\mathrm{i}}$ and $\mathrm{N} 2 \ldots$ $\mathrm{H} 12^{\mathrm{ii}}-\mathrm{C} 12^{\mathrm{ii}}$ angles are 128 and $127^{\circ}$, respectively. The hydrogen-bonded chain that results from these interactions is further supported by F ... HC hydrogen bonds (Figure 11a) with F2 .. H $2^{\mathrm{i}}$ and $\mathrm{F} 11 \ldots \mathrm{H} 11^{\mathrm{ii}}$ separations of 2.46 and $2.41 \AA$, and $\mathrm{F} 2 \ldots \mathrm{H} 2^{\mathrm{i}}-\mathrm{C} 2^{\mathrm{i}}$ and $\mathrm{F} 11 \ldots \mathrm{H} 11^{\mathrm{ii}}-\mathrm{C} 11^{\mathrm{ii}}$ angles of $166^{\circ}$ and $160^{\circ}$, respectively. The zigzag profile of the hydrogen-bonded assembly (which runs along the crystallographic $c$ axis) is shown in Figure 11b. The chains pack with pairs of tpy domains of adjacent chains lying in a head-to-tail arrangement with optimal $\pi$-stacking of the central pyridine rings (Figure 12). The separation of the planes of the rings containing N3 and N 3 iii is $3.37 \AA$, and the inter-centroid distance is $3.69 \AA$ (symmetry code iii $=-x, 1-y,-z$ ). In 5 , a combination of 
hydrogen-bonding and the $\pi$-stacking of tpy units leads to highly efficient crystal packing with close approach of $\mathrm{CF}_{3}$ groups as shown in Figure S19. The closest F ... F contact is 2.54(1) $\AA$, which is less than the sum of the van der Waals radii (2.94 $₫$ [32], 2.70 $\AA$ [42]).

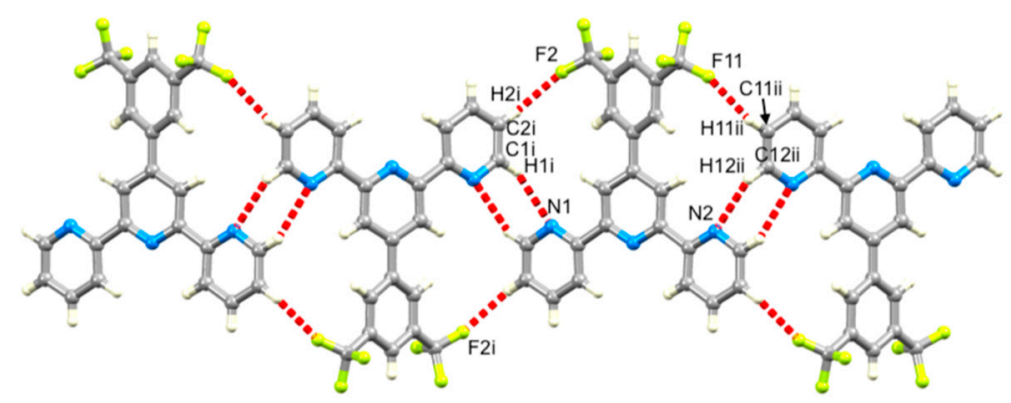

(a)

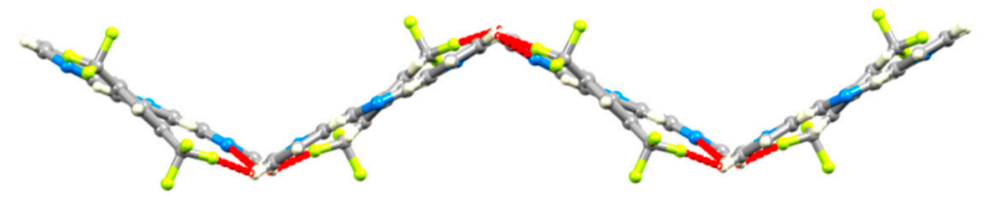

(b)

Figure 11. Assembly of part of a hydrogen-bonded chain in 5, showing (a) the N .. H-C and F ... $\mathrm{H}-\mathrm{C}$ interactions (symmetry codes $\mathrm{i}=-x, y,-1 / 2-z ; \mathrm{ii}=-x, y, 1 / 2-z$ ) and (b) the zigzag profile of the chain. The chain follows the crystallographic $c$-axis.

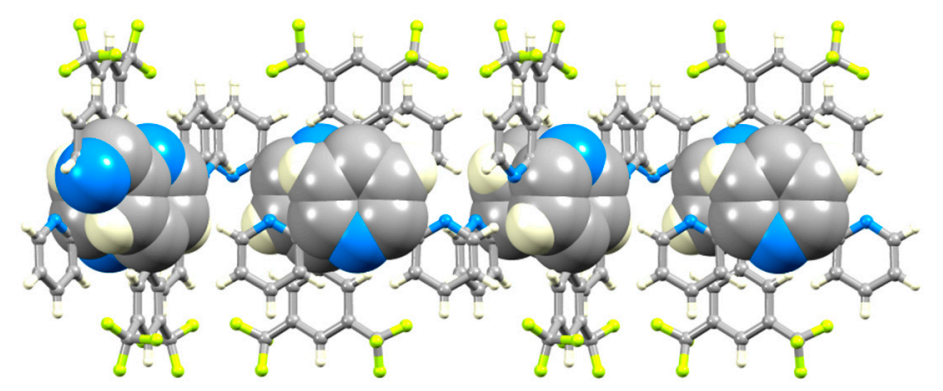

Figure 12. $\pi$-Stacking interactions between tpy domains of adjacent hydrogen-bonded chains in 5 .

The effect of going from a 3,5-bis(trifluoromethyl)phenyl substituent in $\mathbf{5}$ to a 3,5-bis(tert-butyl)phenyl group in $\mathbf{6}$ is difficult to assess because $\mathbf{6}$ crystallizes as the solvate 6. EtOH. As discussed earlier, the $\mathrm{EtOH}$ molecule is hosted within a cavity between a pyridine ring and tert-butyl group, and is associated with the formation of $\pi$-stacked pairs of tpy units (Figure 8). This is, in fact, the dominant packing motif in $\mathbf{6} \cdot \mathrm{EtOH}$. The centrosymmetric dimeric units (Figure $8 \mathrm{~b}$ ) pack with close association of a tert-butyl of one dimer with a pyridine ring of the next. Figure 13 illustrates this packing, and the closest $\mathrm{H}_{\text {tert-butyl }}$... centroid $\mathrm{c}_{\text {pyridine }}$ distance is $3.14 \AA$. 


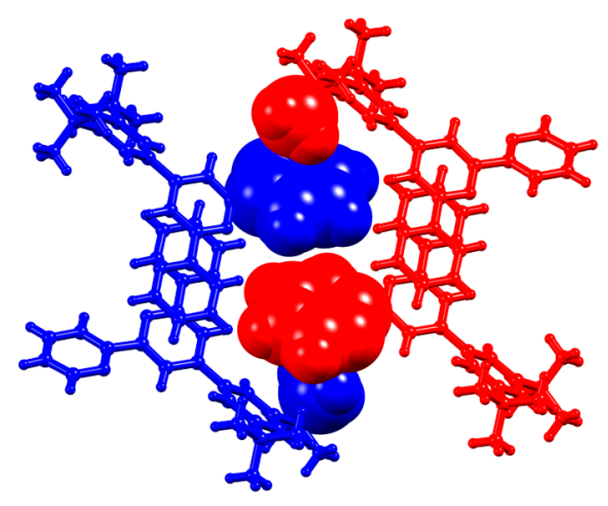

Figure 13. Adjacent centrosymmetric dimers $\{\mathbf{6} \cdot \mathrm{EtOH}\}_{2}$ colored blue and red (EtOH molecules omitted for clarity) associate through $\mathrm{CH}_{\text {tert-butyl }} \ldots$ centroid $_{\text {pyridine }}$ contacts; methyl groups (of the tert-butyl) and pyridine rings are shown in space-filling representation. The central red and blue pyridine rings are not $\pi$-stacked.

\section{Conclusions}

We have described the preparation of a series of new $4^{\prime}$-substituted tpys 2-5. Characterization has been carried out by mass spectrometry and solution NMR and absorption spectroscopies. The single-crystal X-ray diffraction structures of 3 and 5 have been determined along with that of compound 6.EtOH. At the molecular level, these structures show no unexpected features, although the $4^{\prime}$-phenyl ring is twisted with respect to the central pyridine ring through an angle of $28.2^{\circ}$ in 3 , $20.4^{\circ}$ in 5 , and $40.5^{\circ}$ in 6 , which is significantly larger than the $10.9^{\circ}$ observed in the parent compound 1 [24]. Since 1, 3 and 5 crystallize without lattice solvent, we are able to observe the influence of introducing substituents in the $4^{\prime}$-phenyl ring, in particular that of the fluoro- or trifluoromethyl substituents. On going from 1 to 3 , face-to-face $\pi$-stacking of pairs of 3-fluoro-5-methylphenyl rings contributes to a switch in packing from a herringbone assembly in $\mathbf{1}$ with no $\pi$-stacking of aromatic rings to a layer-like packing. The latter arises through a combination of $\mathrm{N} \ldots \mathrm{H}-\mathrm{C}$ hydrogen bonding and $\pi$-stacking. On going from 3 to $5, \mathrm{~N} \ldots \mathrm{H}-\mathrm{C}$ and $\mathrm{F} \ldots \mathrm{H}-\mathrm{C}$ hydrogen-bonding is a principal factor in the crystal packing and is augmented by $\pi$-stacking interactions between pairs of pyridine rings. An N ... H-C hydrogen-bonded motif is retained in both 3 and 5 . A comparison of the packing in 6 with that in 1, 3 and 5 is not possible because of the incorporation of solvent in $6 \cdot \mathrm{EtOH}$. Nonetheless, it is interesting that the tert-butyl groups are involved in short $\mathrm{CH}_{\text {tert-butyl }} \ldots$ centroid ${ }_{\text {pyridine }}$ contacts, which lead to an association of centrosymmetric $\{\mathbf{6} \cdot \mathrm{EtOH}\}_{2}$ dimers.

Supplementary Materials: The following are available online at http:/ /www.mdpi.com/2073-4352/9/2/110/s1. Figures S1-S4: Mass spectra; Figures S5-S17: Additional NMR spectra; Figures S18 and S19: Packing diagrams for 3 and 5 ; cifs for 3,5 and $6 \cdot \mathrm{EtOH}$.

Author Contributions: Y.M.K. and M.K.: Synthesis and characterization, consolidation of data and contributions to manuscript preparation; A.P.: Crystallography; E.C.C.: Group leader, project concepts and contributions to manuscript preparation; C.E.H.: Group leader, project concepts and manuscript preparation.

Funding: We thank the Swiss National Science Foundation (Grant number: 200020_162631) and the University of Basel for support.

Conflicts of Interest: The authors declare no conflict of interest.

\section{References}

1. Desiraju, G.R. Crystal Engineering: From Molecule to Crystal. J. Am. Chem. Soc. 2013, 135, 9952-9967. [CrossRef] [PubMed]

2. Desiraju, G.; Steiner, T. The Weak Hydrogen Bond in Structural Chemistry and Biology; Oxford University Press: Oxford, UK, 1999; ISBN 9780198509707. 
3. Grabowski, S.J. $[\mathrm{FHF}]^{-}$- The Strongest Hydrogen Bond under the Influence of External Interactions. Crystals 2016, 6, 3. [CrossRef]

4. Steiner, T. The Hydrogen Bond in the Solid State. Angew. Chem. Int. Ed. 2002, 41, 48-76. [CrossRef]

5. Thakuria, R.; Sarma, B.; Nangia, A. Hydrogen bonding in molecular crystals. In Comprehensive Supramolecular Chemistry II; Atwood, J.L., Ed.; Elsevier: Amsterdam, The Netherlands, 2017; Chapter 7.03; pp. 25-48. ISBN 978-0-12-803199-5.

6. Nishio, M. CH/ $\pi$ hydrogen bonds in crystals. CrystEngComm 2004, 6, 130-158. [CrossRef]

7. Suezawa, H.; Yoshida, T.; Umezawa, Y.; Tsuboyama, S.; Nishio, M. CH/ $\pi$ Interactions Implicated in the Crystal Structure of Transition Metal Compounds-A Database Study. Eur. J. Inorg. Chem. 2002, 3148-3155. [CrossRef]

8. Taylor, R. It Isn't, It Is: The C-H . X X (X = O, N, F, Cl) Interaction Really is Significant in Crystal Packing. Cryst. Growth Des. 2016, 16, 4165-4168. [CrossRef]

9. Gavezzotti, A.; Lo Presti, L. Building Blocks of Crystal Engineering: A Large Database Study of the Intermolecular Approach between $\mathrm{C}-\mathrm{H}$ Donor groups and $\mathrm{O}, \mathrm{N}, \mathrm{Cl}$, or $\mathrm{F}$ Acceptors in Organic Crystals. Cryst. Growth Des. 2016, 16, 2952-2962. [CrossRef]

10. Lo Presti, L. On the significance of weak hydrogen bonds in crystal packing: A large databank comparison of polymorphic structures. CrystEngComm 2018, 20, 5976-5989. [CrossRef]

11. Gatsiou, C.A.; Adjiman, C.S.; Pantelides, C.C. Repulsion-dispersion parameters for the modelling of organic molecular crystals containing N, O, S and Cl. Faraday Discuss. 2018, 211, 297-323. [CrossRef] [PubMed]

12. Nyman, J.; Reutzel-Edens, S.M. Crystal structure prediction is changing from basic science to applied technology. Faraday Discuss. 2018, 211, 459-476. [CrossRef]

13. Price, S.L. Is zeroth order crystal structure prediction (CSP_0) coming to maturity? What should we aim for in an ideal crystal structure prediction code? Faraday Discuss. 2018, 211, 9-30. [CrossRef] [PubMed]

14. Price, S.L. Why don't we find more polymorphs? Acta Cryst. 2013, B69, 313-328. [CrossRef] [PubMed]

15. Price, S.L. From crystal structure prediction to polymorph prediction: Interpreting the crystal energy landscape. Phys. Chem. Chem. Phys. 2008, 10, 1996-2009. [CrossRef] [PubMed]

16. Constable, E.C. $2,2^{\prime}: 6^{\prime}, 2^{\prime \prime}$-Terpyridines: From chemical obscurity to common supramolecular motifs. Chem. Soc. Rev. 2007, 36, 246-253. [CrossRef] [PubMed]

17. Constable, E.C. The coordination chemistry of $2,2^{\prime}: 6^{\prime}, 2^{\prime \prime}$-terpyridine and higher oligopyridines. Adv. Inorg. Chem. Radiochem. 1986, 30, 69-121. [CrossRef]

18. Housecroft, C.E. Divergent $4,2^{\prime}: 6^{\prime}, 4^{\prime \prime}$ - and $3,2^{\prime}: 6^{\prime}, 3^{\prime \prime}$-terpyridines as linkers in 2- and 3-dimensional architectures. CrystEngComm 2015, 17, 7461-7468. [CrossRef]

19. Constable, E.C.; Housecroft, C.E. Tetratopic bis $\left(4,2^{\prime}: 6^{\prime}, 4^{\prime \prime}\right.$-terpyridine $)$ and $\operatorname{bis}\left(3,2^{\prime}: 6^{\prime}, 3^{\prime \prime}\right.$-terpyridine $)$ ligands as 4-connecting nodes in 2D-coordination networks and 3D-frameworks. J. Inorg. Organomet. Polym. Mater. 2018, 28, 414-427. [CrossRef]

20. Hunter, C.A.; Lawson, K.R.; Perkins, J.; Urch, C.J. Aromatic Interactions. J. Chem. Soc. Perkin Trans. 2 2001, 651-669. [CrossRef]

21. Janiak, C. A critical account on $\pi-\pi$ stacking in metal complexes with aromatic nitrogen-containing ligands. Dalton Trans. 2000, 3885-3896. [CrossRef]

22. McMurtrie, J.; Dance, I. Crystal packing in metal complexes of $4^{\prime}$-phenylterpyridine and related ligands: Occurrence of the 2D and 1D terpy embrace arrays. CrystEngComm 2009, 11, 1141-1149. [CrossRef]

23. McMurtrie, J.; Dance, I. Alternative two-dimensional embrace nets formed by metal complexes of 4'-phenylterpyridine crystallised with hydrophilic anions. CrystEngComm 2010, 12, 3207-3217. [CrossRef]

24. Constable, E.C.; Lewis, J.; Liptrot, M.C.; Raithby, P.R. The coordination chemistry

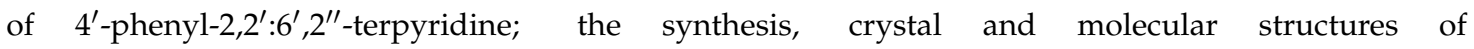
$4^{\prime}$-phenyl-2,2' $: 6^{\prime}, 2^{\prime \prime}$-terpyridine and bis $\left(4^{\prime}\right.$-phenyl-2,2' $: 6^{\prime}, 2^{\prime \prime}$-terpyridine)nickel(II) chloride decahydrate. Inorg. Chim. Acta 1990, 178, 47-54. [CrossRef]

25. Tu, S.; Jia, R.; Zhang, J.; Zhang, Y.; Yao, C.; Ji, S. Kröhnke reaction in aqueous media: One-pot clean synthesis of $4^{\prime}$-aryl-2,2': $6^{\prime}, 2^{\prime \prime}$-terpyridines. Tetrahedron 2007, 63, 381-388. [CrossRef]

26. Nayak, S.K.; Sathishkumar, R.; Row, T.N.G. Directing role of functional groups in selective generation of $\mathrm{C}-\mathrm{H} \cdots \pi$ interactions: In situ cryo-crystallographic studies on benzyl derivatives. CrystEngComm 2010, 12, 3112-3118. [CrossRef] 
27. Boden, N.; Davis, P.P.; Stam, C.H.; Wesselink, G.A. Solid hexafluorobenzene I. The crystal structure at 120 K. Mol. Phys. 1973, 25, 81-86. [CrossRef]

28. Prasanna, M.D.; Row, T.N.G. C-halogen $\cdots \pi$ interactions and their influence on molecular conformation and crystal packing: A database study. Cryst. Eng. 2000, 3, 135-154. [CrossRef]

29. Overell, J.S.W.; Pawley, G.S. An X-ray single-crystal study of the molecular system $\mathrm{C}_{6} \mathrm{~F}_{6} \cdot \mathrm{C}_{6} \mathrm{D}_{6}$. Acta Cryst. 1982, B38, 1966-1972. [CrossRef]

30. Williams, J.H.; Cockcroft, J.K.; Fitch, A.N. Structure of the Lowest Temperature Phase of the Solid Benzene-Hexafluorobenzene Adduct. Angew. Chem. Int. Ed. 1992, 31, 1655-1657. [CrossRef]

31. Reichenbächer, K.; Süssa, H.I.; Hulliger, J. Fluorine in crystal engineering- “The little atom that could". Chem. Soc. Rev. 2005, 34, 22-30. [CrossRef]

32. Berger, R.; Resnati, G.; Metrangolo, P.; Weber, E.; Hulliger, J. Organic fluorine compounds: A great opportunity for enhanced materials properties. Chem. Soc. Rev. 2011, 40, 3496-3508. [CrossRef] [PubMed]

33. Wang, J.; Hanan, G.S. A facile route to sterically hindered and non-hindered $4^{\prime}$-aryl-2,2' $: 6^{\prime}, 2^{\prime \prime}$-terpyridines. Synlett 2005, 1251-1254. [CrossRef]

34. Collin, J.-P.; Dixon, I.M.; Sauvage, J.-P.; Williams, J.A.G.; Barigelletti, F.; Flamigni, L. Synthesis and photophysical properties of iridium(III) bisterpyridine and its homologues: A family of complexes with a long-lived excited state. J. Am. Chem. Soc. 1999, 121, 5009-5016. [CrossRef]

35. APEX2, Version 2 User Manual, M86-E01078; Bruker Analytical X-ray Systems Madison Inc: Madison, WI, USA, 2006.

36. Palatinus, L.; Chapuis, G. SUPERFLIP-A computer program for the solution of crystal structures by charge flipping in arbitrary dimensions. J. Appl. Cryst. 2007, 40, 786-790. [CrossRef]

37. Betteridge, P.W.; Carruthers, J.R.; Cooper, R.I.; Prout, K.; Watkin, D.J. CRYSTALS Version 12: Software for Guided Crystal Structure Analysis. J. Appl. Cryst. 2003, 36, 1487. [CrossRef]

38. Dolomanov, O.V.; Bourhis, L.J.; Gildea, R.J.; Howard, J.A.K.; Puschmann, H. OLEX2: A complete structure solution, refinement and analysis program. J. Appl. Cryst. 2009, 42, 339-341. [CrossRef]

39. Macrae, C.F.; Edgington, P.R.; McCabe, P.; Pidcock, E.; Shields, G.P.; Taylor, R.; Towler, M.; van de Streek, J. Mercury: Visualization and analysis of crystal structures. J. Appl. Cryst. 2006, 39, 453-457. [CrossRef]

40. Macrae, C.F.; Bruno, I.J.; Chisholm, J.A.; Edgington, P.R.; McCabe, P.; Pidcock, E.; Rodriguez-Monge, L.; Taylor, R.; van de Streek, J.; Wood, P.A. Mercury CSD 2.0-New Features for the Visualization and Investigation of Crystal Structures. J. Appl. Cryst. 2008, 41, 466-470. [CrossRef]

41. Groom, C.R.; Bruno, I.J.; Lightfoot, M.P.; Ward, S.C. The Cambridge Structural Database. Acta Crystallogr. Sect. B 2016, 72, 171-179. [CrossRef]

42. Emsley, J. The Elements, 3rd ed.; Clarendon Press: Oxford, UK, 1998; ISBN 0-198-55818-X. 